\title{
HUBUNGAN TINGKAT KECERDASAN EMOSIONAL DAN SPIRITUAL TERHADAP PERILAKU CARING PERAWAT PELAKASANA DI RUMAH SAKIT UNIVERSITAS TANJUNGPURA PONTIANAK
}

\author{
RELATIONSHIP BETWEEN OF EMOTIONAL AND SPIRITUAL INTELLIGENCE WITH \\ NURSE CARING BEHAVIOR IN HOSPITAL OF TANJUNGPURA UNIVERSITY \\ PONTIANAK
}

\begin{abstract}
Nia Zulfita*, Maria Fudji Hastuti**, Arina Nurfianti***
*Mahasiswi Prodi Keperawatan Fakultas Kedokteran Universitas Tanjungpura, Pontianak zulfitania@student.untan.ac.id **Dosen Keperawatan Fakultas KedokteranUniversitas Tanjungpura, Pontianak ***Dosen Keperawatan Fakultas Kedokteran Universitas Tanjungpura, Pontianak
\end{abstract}

\begin{abstract}
ABSTRAK
Latar Belakang: Perilaku caring yang didukung oleh kecerdasan emosional dan spiritual yang baik dapat mempengaruhi kepuasan pasien. Kepuasan pasien merupakan salah satu indikator mutu pelayanan rumah sakit di Rumah Sakit Universitas Tanjungpura Pontianak dirasa masih kurang karena masih terdapat perawat yang belum berperilaku caring sehingga mempengaruhi kualitas asuhan keperawatan dan kepuasan pasien.

Tujuan penelitian: Mengetahui hubungan kecerdasan emosional dan spiritual dengan perilaku caring perawat pelaksana di Rumah Sakit Universitas Tanjungpura Pontianak.

Metode: Penelitian cross-sectional dengan menggunakan uji chi-square pada 48 sampel dengan metode total sampling.

Hasil: Mayoritas responden memiliki tingkat kecerdasan emosional tinggi $(56,25 \%)$, kecerdasan spiritual tinggi $(60,4 \%)$ dan berperilaku caring baik $(62,5 \%)$. Hasil penelitian terdapat hubungan antara kecerdasan emosional dengan perilaku caring $(p=0,018)$ dan terdapat hubungan antara kecerdasan spiritual dengan perilaku caring $(p=0,032)$. Variabel kecerdasan emosional merupakan faktor yang paling berhubungan dengan perilaku caring perawat $(\mathrm{OR}=4,667)$.

Kesimpulan: Terdapat hubungan antara kecerdasan emosional dan spiritual terhadap perilaku caring perawat pelaksana di Rumah Sakit Universitas Tanjungpura Pontianak. Hasil penelitian ini menyarankan pentingnya meningkatkan perilaku caring yang didasari oleh kecerdasan emosional dan spiritual perawat.
\end{abstract}

Kata Kunci: Kecerdasan emosional, kecerdasan spiritual, perilaku caring, perawat Referensi: 83 (2009 - 2018) 


\begin{abstract}
Background: Caring behavior based on emotional and spiritual intelligence that can induce patient satisfaction. At hospital of Tanjungpura University is considered has less rate of patient satisfaction.

Objective: To find out the relationship between emotional and spiritual intelligence and nurse caring behavior at hospital of Tanjungpura University Pontianak.

Method: A cross-sectional study in 48 samples. The result of this study was analyzed with Chisquare test.

Results: The majority of respondents had a high level of emotional intelligence (56.25\%), high spiritual intelligence (60.4\%) and good caring behavior (62.5\%). The results of the study there is a relationship between emotional intelligence and caring behavior $(p=0.018)$ and there is a relationship between spiritual intelligence and caring behavior $(p=0.032)$. The emotional intelligence variable is the factor most associated with nurse caring behavior (OR $=4,667)$.

Conclusion: There is a relationship between emotional and spiritual intelligence with nurse caring behavior at Hospital of Tanjungpura University Pontianak. The results of this study suggest the importance of increasing caring behavior based on the emotional and spiritual intelligence of nurses.
\end{abstract}

Keywords: Emotional intelligence, spiritual intelligence, caring behavior, nurses

Reference: 83 (2009 - 2018) 


\section{PENDAHULUAN}

Keberhasilan pelayanan kesehatan dipengaruhi oleh partisipasi perawat yang merupakan ujung tombak dari pelayanan kesehatan dalam memberikan pelayanan kesehatan yang berkualitas kepada pasien (Anjaswarni,2012). Pelayanan kesehatan yang berkualitas dapat diwujudkan melalui pemberian asuhan keperawatan yang didasari oleh perilaku caring perawat (Ardiana,2010).

Caring dipandang sebagai ideal moral keperawatan. Penelitian yang berjudul Meaning Of Caring During Their First Year Of Clinical Practice, menyebutkan bahwa perilaku caring yang diharapkan oleh pasien terhadap perawat mencakup kepribadian yang ramah, dedikasi terhadap tugas, empati terhadap pasien dan respon cepat terhadap kebutuhan pasien (Greenfield,2009). Caring diyakini dapat meningkatkan kesehatan pasien dan kesejahteraan serta memfasilitasi promosi kesehatan (Khademian \& Vizeshfar,2009).

Perilaku caring perawat merupakan inti atau fokus dari praktek keperawatan professional, harus dapat diterima dan dirasakan oleh klien. Perilaku caring yang ditampilkan perawat dapat mempengaruhi kepuasan pasien (Sukesi,2012). Penelitian mengenai perilaku caring dan hubungannya dengan kepuasan klien yang dilakukan di instalasi rawat inap bedah dewasa RS Dr. Mohammad Hoesin Palembang, mengungkapkan bahwa perilaku caring perawat cenderung meningkatkan kepuasan pasien (Agustin,2002 dalam Mulyaningsih, 2011).

Caring yang merupakan esensi dari keperawatan masih belum memiliki perhatian yang khusus di Rumah Sakit Universitas Tanjungpura Pontianak. Berdasarkan hasil observasi dan wawancara peneliti terhadap beberapa pasien mengatakan bahwa rata-rata pasien mengatakan puas terhadap pelayanan kesehatan di Rumah Sakit ini. Namun demikian, masih ada keluhan dari pasien terhadap pelayanan dan sikap perawat antara lain kurang ramah, jarang senyum dan hanya sekedar menjalankan tugas sebagai perawat tanpa menanyakan keadaan atau perasaan pasien sehingga tidak menimbulkan rasa nyaman pada pasien ataupun keluarga.

Perilaku caring yang didasari dengan kecerdasan emosional yang baik akan mendukung terciptanya pelayanan keperawatan yang sesuai dengan harapan pasien 
(Ardiana,2010). Dalam penelitian mengenai The impact of service provider emotional intelligence on customer satisfaction menyebutkan bahwa kecerdasan emosional yang baik, yang ditunjukkan oleh pemberi pelayanan kesehatan, mampu meningkatkan laporan tingkat kepuasan pasien dalam berhubungan dengan petugas kesehatan (Kernbach \& Schutte, 2005 dalam Ardiana, 2010). Oleh karena itu, perawat perlu menginternalisasikan kecerdasan emosional yang baik dalam setiap pelayanan yang diberikan kepada pasien.

Kecerdasan emosional menjadi bagian penting dalam keberhasilan pembentukan hubungan manusia. Kecerdasan emosional sangat penting untuk membangun hubungan terapeutik perawat-pasien. Karena, dengan kecerdasan emosional, seseorang tenaga kesehatan akan lebih empati, memiliki rasa kasih dan lebih bijaksana (Anne,2010). Hal ini didukung oleh penelitian yang dilakukan di RSU Padan Arang Boyolali mengenai hubungan kecerdasan emosional dengan kemampuan komunikasi terapeutik perawat yang menemukan adanya hubungan yang signifikan antara kecerdasan emosi dengan kemampuan komunikasi terapeutik perawat (Suwardi, 2009). Selain itu, penelitian lain mengenai Emotional intelligence, performance and retention in clinical staff nurses, menunjukkan bahwa kecerdasan emosional staff perawat klinis memiliki hubungan yang signifikan dengan performa kerja yang baik, karir dan retensi pekerjaan (Codier et all.,2009).

Disamping diperlukannya kecerdasan emosional yang sangat berperan dalam menentukan kesuksesan dan peningkatan prestasi kerja, maka diperlukan pula kombinasi antara kecerdasan emosional dengan kecerdasan spiritual. Perawat dalam menjalankan tugasnya dimotivasi oleh makna dan nilai yang ingin dicapai dalam melakukan perilaku caring. Hal ini berkaitan dengan kecerdasan spiritual yang dimiliki oleh perawat itu sendiri.

Kecerdasan spiritual sangat mendukung peran perawat dalam melaksanakan asuhan keperawatan pada pasien. Penelitian tentang hubungan kecerdasan spiritual dengan perilaku caring perawat di RSUP Haji Adam Malik Medan menunjukkan terdapat hubungan yang positif antara kecerdasan spiritual dengan perilaku caring perawat pada praktek keperawatan (Qomariah, 2012). Hasil penelitian lain mengenai pengaruh kecerdasan emosi dan spiritual terhadap kinerja menunjukkan bahwa 
kecerdasan spiritual memiliki pengaruh positif dan signifikan terhadap kinerja (Sani,2010). Hasil ini bermakna bahwa semakin meningkat tingkat kecerdasan spiritual, maka kinerja akan semakin meningkat.

Penelitian mengenai pengaruh kecerdasan emosi dan spiritual terhadap kinerja mengatakan bahwa kecerdasan emosional dan spiritual perawat berpengaruh signifikan terhadap kinerja, baik secara bersama-sama maupun terpisah (Dewi, 2009). Dengan demikian, kecerdasan emosional dan kecerdasan spiritual perawat akan mempengaruhi perawat dalam melaksanakan pekerjaannya termasuk dalam berperilaku caring pada pemberian pelayanan keperawatan.

Selama ini Rumah Sakit Universitas Tanjungpura belum melakukan upaya-upaya untuk meningkatkan kecerdasan emosional dan spiritual perawat. Padahal kecerdasan emosional dan spiritual perawat terbukti dapat mempengaruhi perawat dalam melaksanakan pekerjaannya termasuk dalam berperilaku caring pada pemberian pelayanan keperawatan. Sehubungan dengan hal tersebut diatas, penulis tertarik untuk meneliti hubungan kecerdasan emosional dan spiritual terhadap perilaku caring perawat pelaksana di rumah sakit Universitas
Tanjungpura Pontianak.

\section{METODE PENELITIAN}

Jenis penelitian ini adalah penelitian kuantitatif dengan desain penelitian studi korelasi. Pengumpulan data dilakukan secara cross sectional, yaitu pendekatan, observasi atau pengumpulan data sekaligus pada suatu saat (Dharma,2011; Notoatmodjo,2012).

Populasi dalam penelitian ini adalah seluruh perawat diruang rawat inap (ICU, Penyakit Dalam, Anak, Perinatologi, Bedah dan Saraf) rumah sakit Universitas Tanjungpura Pontianak yang berjumlah 52 responden dengan tingkat pendidikan minimal D3 Keperawatan. Teknik yang digunakan untuk menentukan sampel penelitian adalah total sampling. Dari 52 responden, terdapat 4 responden yang cuti sehingga dinyatakan drop out. Maka, sampel yang akan diambil dalam penelitian ini adalah sebanyak 48 responden.

Instrumen atau alat ukur yang digunakan dalam penelitian ini adalah kuisioner dengan pertanyaan tersrukrtur. Kuesioner kecerdasan emosional menggunakan kuesioner adopsi dan modifikasi dari penelitian yang dilakukan oleh Erwin Rudyanto (2010) dengan judul penelitian "Hubungan antara Kecerdasan Emosi dan Kecerdasan Spiritual dengan 
Perilaku Prososial pada Perawat di Rumah Sakit Islam Klaten" yang dikembangkan dari dimensi kecerdasan emosional oleh Goleman. Pengembangan kuesioner ini disesuaikan dengan kondisi setempat, menggunakan bahasa yang mudah dimengerti oleh responden. Kuesioner ini terdiri dari 31 pernyataan. Kuesioner kecerdasan spritual menggunakan kuesioner Spiritual intelligence self-report inventory (SISRI) yang terdiri dari 24 pertanyaan dan untuk mengukur tingkat caring perawat menggunakan lembar observasi yang merupakan modifikasi dari kuesioner yang disusun oleh Mulyaningsih (2011) dengan penelitiannya yang berjudul "Hubungan Berpikir Kritis dengan Perilaku Caring Perawat di RSUD Dr. Moewardi Surakarta”. Lembar observasi ini terdiri dari 36 pernyataan.

Penelitian ini menggunakan uji normalitas data Shapiro-wilk karena jumlah responden kurang dari 50. Pada distribusi skor kecerdasan emosional, kecedasan spiritual serta perilaku caring perawat didapatkan data berdistribusi normal dengan nilai $p=0,299$. 


\section{HASIL PENELITIAN}

Hasil penelitian dibagi menjadi

2 yaitu analisa univariate dan bivariate. Analisis univariat pada penelitian ini akan menguraikan gambaran karakteristik perawat, gambaran kecerdasan emosional perawat, gambaran kecerdasan spiritual perawat dan gambaran perilaku caring perawat sedangkan analisa bivariat dilakukan untuk mengetahui hubungan antara variabel independen yaitu kecerdasan emosional dan kecerdasan spiritual dengan variabel dependen yaitu perilaku caring.

Tabel 1 Distribusi Data berdasarkan Karakteristik Responden (n=48)

\begin{tabular}{cccc}
\hline \multicolumn{2}{c}{ Karakteristik Responden } & $\mathrm{F}$ & $\%$ \\
\hline Usia & $17-25$ Tahun & 27 & 56,3 \\
& $26-35$ Tahun & 21 & 43,7 \\
\hline \multirow{2}{*}{ Jenis Kelamin } & Laki - laki & 17 & 35,4 \\
& Perempuan & 31 & 64,6 \\
\hline Pendidikan Terakhir & D3 & 13 & 27,1 \\
& D4 & 1 & 2,1 \\
& S1/Ners & 34 & 70,8 \\
\hline Masa Kerja & $1-5$ Tahun & 39 & 81,3 \\
& $>5$ Tahun & 9 & 18,7 \\
\hline Sumber : Data Primer (2019) & & &
\end{tabular}

Berdasarkan data pada tabel diatas didapatkan mayoritas responden berada pada umur dengan kategori 17

- 25 tahun sebesar 27 orang dengan persentase 56,3\%. Mayoritas jenis kelamin responden yaitu berjenis kelamin perempuan sebesar
31 orang dengan persentase $64,6 \%$. Mayoritas pendidikan terakhir responden yaitu S1/Ners sebanyak 34 orang dengan persentase $70,8 \%$. Dan mayoritas masa kerja responden yaitu 1-5 tahun sebesar 39 orang dengan persentase $81,3 \%$.

Tabel 2 Distribusi Data Kecerdasan Emosional Perawat $(n=48)$

\begin{tabular}{ccc}
\hline Kecerdasan Emosional & F & \% \\
\hline Tinggi & 27 & 56,25 \\
Rendah & 21 & 43,75 \\
\hline Sumber : Data Primer (2019) & &
\end{tabular}

Dari Tabel 2 dapat dilihat bahwa mayoritas responden memiliki tingkat kecerdasan emosional tinggi sebanyak 27 orang dengan persentase
$56,25 \%$ dan yang memiliki kecerdasan emosional rendah sebanyak 21 orang dengan persentase $43,75 \%$. 
Tabel 3 Distribusi Data Kecerdasan Spiritual Perawat $(n=48)$

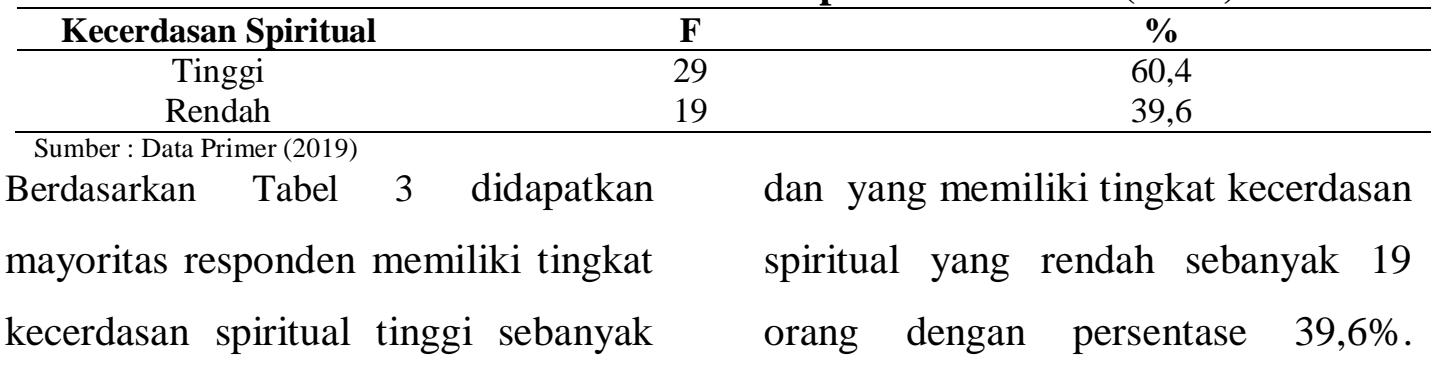

29 orang dengan persentase $60,4 \%$

Tabel 4 Distribusi Data Perilaku Caring Perawat $(n=48)$

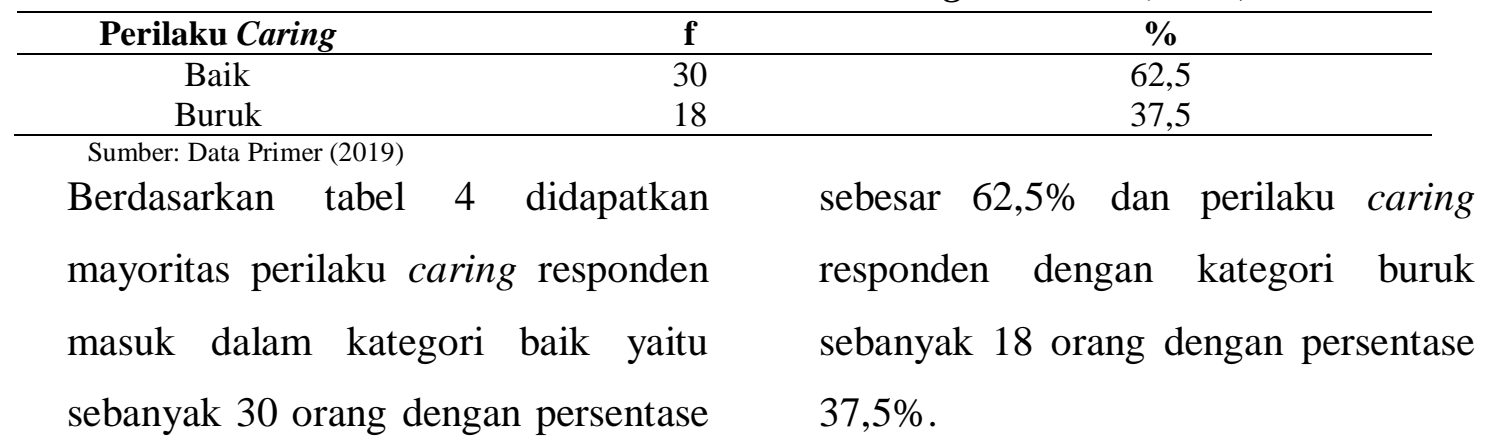

Tabel 5 Analisis Hubungan Kecerdasan Emosional terhadap Perilaku Caring Perawat Pelaksana di Rumah Sakit Universitas Tanjungpura Pontianak

\begin{tabular}{ccccccc}
\hline & \multicolumn{3}{c}{ Perilaku Caring } & & OR \\
\cline { 2 - 5 } Kecerdasan & \multicolumn{2}{c}{ Baik } & \multicolumn{2}{c}{ Buruk } & & (95\% CI) \\
\cline { 2 - 5 } Emosional & $\mathrm{N}$ & $\%$ & $\mathrm{~N}$ & $\%$ & 4,667 & 0,018 \\
\hline Tinggi & 21 & 77,8 & 6 & 22,2 & & \\
Rendah & 9 & 42,9 & 12 & 57,1 & $1,333-16,338$ & \\
\hline Total & 30 & 62,5 & 18 & 37,5 & & \\
\hline Sumber: Uji Chi Square & & & & &
\end{tabular}

Berdasarkan tabel 5 didapatkan berjumlah 6 orang dengan persentase bahwa perawat dengan kecerdasan 22,2\%. Kecerdasan emosional rendah emosional tinggi dan memiliki pada perawat yang memiliki perilaku perilaku caring baik berjumlah 21 caring baik berjumlah 9 orang dengan orang dengan persentase $77,8 \%$ persentase $42,9 \%$ sedangkan sedangkan perawat dengan kecerdasan emosional rendah dengan kecerdasan emosional tinggi dan perilaku caring buruk berjumlah 12 memiliki perilaku caring buruk orang dengan persentase $57,1 \%$. 
Tabel 6 Analisis Hubungan Kecerdasan Spiritual terhadap Perilaku Caring Perawat Pelaksana di Rumah Sakit Universitas Tanjungpura Pontianak

\begin{tabular}{|c|c|c|c|c|c|c|}
\hline \multirow{3}{*}{$\begin{array}{c}\text { Kecerdasan } \\
\text { Spiritual }\end{array}$} & \multicolumn{4}{|c|}{ Perilaku Caring } & \multirow{3}{*}{$\begin{array}{c}\text { OR } \\
(95 \% \mathrm{CI})\end{array}$} & \multirow{3}{*}{$P$} \\
\hline & \multicolumn{2}{|c|}{ Baik } & \multicolumn{2}{|c|}{ Buruk } & & \\
\hline & $\mathrm{N}$ & $\%$ & $\mathrm{~N}$ & $\%$ & & \\
\hline Tinggi & 22 & 75,9 & 7 & 24,1 & 4,321 & 0,032 \\
\hline Rendah & 8 & 42,1 & 11 & 57,9 & $1,234-15,025$ & \\
\hline Total & 30 & 62,5 & 18 & 37,5 & & \\
\hline
\end{tabular}

Berdasarkan tabel 6 didapatkan bahwa perawat dengan kecerdasan spiritual tinggi dan memiliki perilaku caring baik berjumlah 22 orang dengan persentase $75,9 \%$ sedangkan perawat dengan kecerdasan spiritual tinggi dan memiliki perilaku caring buruk berjumlah 7 orang dengan persentase $24,1 \%$. Kecerdasan spiritual rendah pada perawat yang memiliki perilaku caring baik berjumlah 8 orang dengan persentase $42,1 \%$ sedangkan kecerdasan spiritual rendah dengan perilaku caring buruk berjumlah 11 orang dengan persentase $57,9 \%$.

\section{PEMBAHASAN}

Berdasarkan hasil uji statistik yang dilakukan untuk mengetahui hubungan kecerdasan emosional dengan perilaku caring perawat diperoleh nilai $p$ value $=0,018$ yang berarti ada hubungan antara kecerdasan emosional dengan perilaku caring perawat pelaksana di Rumah Sakit Universitas Tanjungpura Pontianak. Kecerdasan emosional perawat secara signifikan berhubungan dengan performa kerja yang baik (Codier, et all, 2009). Dengan kecerdasan emosional yang tinggi yang dimiliki oleh perawat Rumah Sakit Universitas Tanjungpura Pontianak, maka diharapkan performa kerja yang ditampilkan juga baik. Hasil penelitian ini relevan dengan penelitian Nastasa (2015) yang menemukan hasil bahwa perawat yang memiliki kecerdasan emosional tinggi lebih mampu beradaptasi ketika merawat pasien. Perawat yang memiliki kecerdasan emosional yang tinggi dipersepsikan lebih caring oleh pasien dibandingkan perawat yang memiliki kecerdasan emosional yang rendah.

Hasil penelitian ini sesuai dengan penelitian Hidayati (2017) yang menunjukkan ada korelasi yang signifikan antara kecerdasan emosional dan perilaku caring perawat. Hasil penelitian ini didukung oleh hasil penelitian Ridwan (2017) yang mengatakan terdapat hubungan yang signifikan antara kecerdasan emosional perawat dengan perilaku caring perawat di ruang rawat inap Rumah Sakit Penambahan Senopati Bantul. Perilaku caring yang didasari dengan 
kecerdasan emosional yang baik akan mendukung terciptanya pelayanan keperawatan yang sesuai dengan harapan pasien. Perilaku caring berhubungan erat dengan empati. Perawat yang mampu berperilaku caring akan menunjukkan empati kepada pasien yang merupakan aspek kecerdasan emosional (Raghubir, 2018). Kecerdasan emosional yang tinggi secara tidak langsung akan mengarahkan perawat memberikan perilaku caring yang baik pada pasien (Hidayati, 2017).

Kemudian hasil uji statistik yang dilakukan untuk mengetahui hubungan kecerdasan spiritual dengan perilaku caring perawat diperoleh nilai $p$ value $=0,032$ yang berarti ada hubungan antara kecerdasan spiritual dengan perilaku caring perawat pelaksana di Rumah Sakit Universitas Tanjungpura Pontianak. Hasil penelitian ini didukung oleh penelitian Anggriani (2014) yang menunjukkan hubungan yang signifikan antara kecerdasan spiritual dengan perilaku caring perawat pada praktik keperawatan di ruang rawat inap Rumah Sakit Umum Daerah Nagan Raya.

Zohar \& Mrashall (2009) menyatakan kecerdasan spiritual mempunyai beberapa aspek, yaitu kemampuan bersikap fleksibel, tingkat kesadaran diri yang tinggi, kemampuan untuk menghadapi dan memanfaatkan penderitaan, kemampuan untuk menghadapi dan melampaui rasa sakit, kualitas hidup yang diilhami visi dan nilai, keengganan untuk menyebabkan kerugian yang tidak perlu, berpikir secara holistik, kecenderungan untuk bertanya mengapa dan bagaimana, dan menjadi pribadi mandiri. Kecerdasan spiritual yang digunakan untuk menempatkan, memaknai, dan menilai kehidupan dalam konteks yang lebih luas dapat dikembangkan dan dihasilkan dari pengalaman kehidupan sehari-hari. Perawat yang mengintegrasikan profesi dengan spiritualitas dapat membuat perawat menjadi perawat yang lebih baik. Pengaruh spiritualitas dan kecerdasan spiritual yang digunakan dapat memungkinkan perawat untuk memecahkan masalah mereka dengan pendekatan spiritual yang dapat mencapai kesejahteraan dan aktualisasi diri (Rani et al, 2013).

Seseorang yang cerdas secara spiritual tidak hanya cerdas dalam hal pengetahuan, namun juga mempunyai tingkat kesadaran yang tinggi mengenai spiritualitas, sehingga dapat membuat perawat lebih sensitif, reflektif dan tanggap terhadap makna dan pengalaman hidupnya, dan dengan demikian perawat cenderung akan lebih mudah untuk mempunyai sikap positif terhadap penyediaan perawatan 
spiritual pada pasien (Chiang et al, 2015). Rohman (2009) menyatakan bahwa perawat yang memelihara spiritualitasnya dapat menemukan sumber-sumber internal untuk merawat pasien melalui meningkatnya kenyamanan dalam diri, lebih sensitif terhadap kebutuhan spiritualitas klien, dan memiliki koping yang lebih efektif terhadap stres yang dihadapi dalam memberikan asuhan keperawatan.

\section{Implikasi Keperawatan}

Penelitian ini diharapkan dapat menjadi acuan bagi rumah sakit dan tenaga keperawatan dalam mempertahankan serta meningkatkan penerapan perilaku caring dalam asuhan keperawatan dalam upaya untuk meningkatkan mutu pelayanan di Rumah Sakit Universitas Tanjungpura Pontianak.

\section{Kesimpulan}

Berdasarkan hasil penelitian mengenai Hubungan Kecerdasan Emosional dan Spiritual terhadap Perilaku Caring Perawat Pelaksana di Rumah Sakit Universitas Tanjungpura Pontianak, dapat disimpulkan bahwa;

1. Karakteristik Responden

Hasil penelitian menunjukkan bahwa mayoritas responden berumur dengan kategori 17-25 tahun dengan persentase sebesar
56,3\%, mayoritas jenis kelamin responden yaitu perempuan dengan persentase $64,6 \%$, mayoritas pendidikan terakhir responden yaitu S1/Ners sebesar $70,8 \%$ dan mayoritas masa kerja responden pada rentang 1-5tahun dengan persentase $81,3 \%$.

2. Kecerdasan Emosional Perawat Hasil penelitian menunjukkan mayoritas responden di Rumah Sakit Universitas Tanjungpura Pontianak memiliki tingkat kecerdasan emosional tinggi sebanyak 27 responden dengan persentase $56,25 \%$.

3. Kecerdasan Spiritual Perawat Hasil penelitian menunjukkan mayoritas responden di Rumah Sakit Universitas Tanjungpura Pontianak memiliki tingkat kecerdasan spiritual tinggi sebanyak 29 responden dengan persentase $60,4 \%$.

4. Perilaku Caring Perawat

Hasil penelitian menunjukkan mayoritas responden di Rumah Sakit Universitas Tanjungpura Pontianak memiliki perilaku caring baik sebanyak 30 responden dengan persentase $62,5 \%$.

5. Hubungan Kecerdasan Emosional terhadap Perilaku Caring Perawat Hasil penelitian menunjukkan nilai $p$ value $=0,018(p<0,05)$ yang berarti ada hubungan antara 
kecerdasan emosional dengan perilaku caring perawat pelaksana di Rumah Sakit Universitas Tanjungpura Pontianak.

6. Hubungan Kecerdasan Spiritual terhadap Perilaku Caring Perawat Hasil penelitian menunjukkan nilai $p$ value $=0,032(p<0,05)$ yang berarti ada hubungan antara kecerdasan spiritual dengan perilaku caring perawat pelaksana di Rumah Sakit Universitas Tanjungpura Pontianak.

\section{DAFTAR PUSTAKA}

Anggriani, N. (2014). Hubungan Kecerdasan Spiritual dengan perilaku Caring Perawat Pada Praktikkeperawatan Di Ruang Rawat Inap Rumah Sakit Umum

Daerah Nagan Raya. Skripsi, Universitas Teuku Umar Meulaboh.

Anjaswarni, Tri.(2012). Analisis

Tingkat Kepuasan Klien terhadap Perilaku Caring Perawat di RSUD Dr. Saiful Anwar Malang.

Anne, McQueen. (2010). Emotional Intelligence in Nursing Work. Journal of Advanced Nursing. 47(1), 101-108

Ardiana, A. (2010). Hubungan Kecerdasan Emosional Perawat Dengan Perilaku Caring Perawat Menurut Persepsi
Pasien Di Ruang Rawat Inap RSUD Dr. H. Koesnadi Bondowoso. Tesis, Universitas Indonesia.

Chiang YC, Lee HC, Chu TL, Han CY, Hsiao YC. (2015). The impact of nurse's spiritual health on their attitudes toward spiritual care, profesional, commitment, and caring. Nursing Outlook 2015; (261): 1-10.

Codier, E., Kamikawa, C., Kooker, B. \& Shoultz, J. (2009). Emotional Intelligence, Performance, and Retention in Clinical Staff Nurses. Nursing Administration Quarterly. 33(4), 310-316

Dewi, S. (2009). Pengaruh Kecerdasan Emosional dan Spiritual terhadap Kinerja (Studi Kasus pada Perawat di RSAB Harapan Kita)

Dharma, Kelana Kusuma. (2011). Metodologi Penelitian Keperawatan Panduan Melaksanakan dan Menerapkan Hasil Penelitian. Edisi Revisi. Jakarta: TIM

Greenfield, B.H. (2009). Meaning Of Caring During Their First Year Of Clinical Practice. Journal of Nursing Research. 10-14.

Hidayati, Laily. (2017). Emotional Intelligence and Caring Behavior Among Muslim Nurse: A Study 
in Religious-Based Hospital in Surabaya-Indonesia. Advances in Health Sciences Research, volume 3, 8th International Nursing Conference (INC 2017).

Khademian, Z., \& Vizeshfar, F. (2009). Nursing Student Perception of The Importance of Caring Behaviors. Journal of Advanced Nursing. 61(4), 456462

Mulyaningsih. (2011). Hubungan berpikir kritis dengan perilaku caring perawat di RSUD Dr Moewardi Surakarta. Tesis, Universitas Indonesia.

Nastasa, E.,Laura. (2015). The Effect of Emotional Intelligence on Burnout in Healthcare Professionals. Procedia - Social and Behavioral Sciences, Published by Elsevier Ltd 187 ( 2015 ) $78-82$.

Notoatmodjo, S. (2012). Metodologi

Penelitian Kesehatan. Jakarta: Rineka Cipta

Qomariah, Nurul. (2012).

Hubungan Kecerdasan Spiritual dengan Perilaku Caring Perawat pada Praktik Keperawatan di Ruang Rawat Inap RSUP Haji Adam Malik Medan. Universitas Sumatera Utara
Raghubir, E.,Angelina. (2018).

Emotional Intelligence In Professional Nursing Practice: A Concept Review Using Rodgers's Evolutionary Analysis Approach. International Journal of Nursing Sciences 5 (2018) 126-130.

Rani AA, Abidin I, Hamid MR. (2013). The impact of spiritual intelligence on work performance: case studies in government hospitals of east coast of Malaysia. The Macrotheme Review 2013; 2(3): 46-59.

Rohman. (2009). Faktor-faktor yang berhubungan dengan pemberian asuhan spiritual oleh perawat di RS Islam Jakarta. Tesis, Universitas Indonesia.

Rudyanto, Erwin. (2010). Hubungan antara Kecerdasan Emosi dan Kecerdasan Spiritual dengan Perilaku Prososial pada Perawat. Skripsi, Universitas Sebelas Maret.

Sani, Achmad. (2010). Pengaruh Kecerdasan Emosional dan Kecerdasan Spiritual terhadap Kepemimpinan

Transformasional, Kepuasan Kerja dan Kinerja Manajer (Studi di Bank Syari'ah Kota Malang)

Sukesi, Niken.(2012). Upaya Peningkatan Caring Perawat 
terhadap Kepuasan Pasien di

Ruang Rawat Inap RS Permata

Medika Semarang. Jurnal

Managemen Keperawatan. 1(1),

$15-24$

Suwardi. (2009). Hubungan antara

Kecerdasan Emosional dengan

Kemampuan Komunikasi

Terapeutik Perawat di RSU

Padan Arang Boyolali 
